\title{
MANAJEMEN PENINGKATAN KOMPETENSI LULUSAN DI MADRASAH
}

\author{
Siti Maesaroh \\ Madrasah Tsanawiyah Negeri 1 Pangandaran \\ Jl. Merdeka No.113, Pananjung, Ciamis, Pangandaran, Jawa Barat 46396 \\ Email: smaesaroh889@gmail.com
}

\begin{abstract}
ABSTRAK
Tujuan penelitian ini adalah untuk mengetahui profil kompetensi lulusan di madrasah khususnya pada Mata Pelajaran Sains, kebijakan, perencanaan, pelaksanaan faktor pendukung dan faktor penghambat. Hasil penelitian berdasarkan pengamatan langsung, dokumentasi dan wawancara dengan kepala madrasah, guru, dan staf tata usaha dapat diringkas sebagai berikut: profil kompetensi lulusan di Madrasah dapat dilihat dari hasil ujian nasional pada kurun waktu tiga tahun yang terus mengalami peningkatan serta. Kebijakan kompetensi lulusan madrasah dengan meningkatkan potensi guru dan siswa dan merujuk pada Standar Kompetensi Lulusan pada Mata Pelajaran Sains, tahap perencanaan peningkatan kompetensi lulusan madrasah dengan menganalisis dan mempelajari SKL Mata Pelajaran Sains, pada tahap pelaksanaan peningkatan kompetensi lulusan dimulai dari perencanaan pembelajaran, pelaksanaan pembelajaran dan penilaian pembelajaran, serta faktor pendukung dalam peningkatan kompetensi lulusan madrasah ialah lebih pada motivasi yang ada dalam diri peserta didik karena motivasi mampu menciptakan situasi dalam diri untuk berbuat dan berperilaku sesuai dengan apa yang dikehendaki. Faktor penghambat dalam peningkatan kompetensi lulusan lebih pada sarana prasarana.
\end{abstract}

Kata Kunci: Kompetensi, Lulusan, Madrasah.

\section{ABSTRACT}

The purpose of this reasearch was to determine the profile of graduate competencies in Madrasah especially on science subjects, policy, planning, implementation, supporting factors and inhibiting factors. Based on the research results of direct observations, documentation and interviews with head master, teacher, and staff administration can be summarized as follow: the profile of graduate competencies can be seen from the national exam result in the period of 3 years has increased. The policy of graduate competencies in madrasah by increasing the potential of teachers and students and the policy refers to government regulation on Standards of Graduate Competencies on science subjects, planning to increase graduate competency in Madrasah by analyzing and studying subject SKL, implementation of graduate competency improvement starts from the planning of learning, implementation of learning, 
and assessment of learning, and supporting factors in increasing the competence of graduate in Madrasah is more on the motivation that is in the students because the motivation is able to create situations within themselves to act and behave in accordance with what is desired. The inhibiting factors in increasing the graduate competence is more inadequate facilities.

Keywords: Competencies, Graduate, Madrasah.

\section{PENDAHULUAN}

Madrasah sebagai suatu lembaga layanan jasa pendidikan memposisikan kepala sekolah sebagai manajer pendidikan. Oleh karena itulah madrasah dituntut untuk bertanggung jawab atas seluruh komponen madrasah dan harus meningkatkan mutu pelayanan dan mutu hasil belajar yang berorientasi kepada pemakai, baik internal maupun eksternal, pemerintah maupun lembaga industri atau dunia kerja.

Inti dari madrasah sebagai wahana untuk membina ruh atau praktik hidup keislaman ialah bahwa madrasah perlu dirancang dan diarahkan untuk membantu, membimbing, melatih serta mengajar dan/atau menciptakan suasana agar para peserta didik (lulusannya) menjadi manusia Muslim yang berkualitas. Dalam arti, peserta didik mampu mengembangkan pandangan hidup, sikap hidup dan keterampilan hidup yang berperspektif Islam (Muhaimin, 2012, h. 201).

Peningkatan kualitas sekolah senantiasa bermuara pada peningkatan kualitas lulusan. Dalam pengertian yang paling dasar pada kurikulum berbasis kompetensi (KBK) sebagaimana yang ada di Indonesia dewasa ini, kualitas lulusan adalah tercapainya standar kompetensi lulusan (SKL) yang telah ditetapkan oleh menteri pendidikan. Standar kompetensi tersebut terkait dengan jenjang pendidikan, jenis sekolah, kelas, dan mata pelajaran. Disebut berkualitas manakala lulusan dapat mencapai standar yang telah ditentukan. Semakin tinggi dan melampaui standar semakin berkualitas pula lulusan tersebut. Sebaliknya, semakin jauh dari standar semakin rendah kualitas yang bersangkutan. Penguasaan kompetensi tersebut diukur dalam skor nilai sebagai cermin dari hasil belajar (Zamroni, 2013, h. 2-3).

Dalam manajemen peningkatan kompetensi lulusan di Madrasah dituntut untuk unggul khususnya pada bidang sains dan dilihat dari realita yang ada bahwa prestasi yang cukup rendah dan belum maksimal maka perlu adanya program peningkatan kompetensi lulusan khususnya pada Mata Pelajaran Sains. Secara perlahan namun pasti, madrasah berupaya mengadaptasi tuntutan tersebut. Peningkatan kompetensi siswa tidak bisa dipandang secara pragmatis, terpisah dari bagian-bagiannya yang utuh.

\section{KAJIAN TEORI}

Manajemen merupakan proses merencanakan, mengorganisasikan, memimpin dan mengendalikan organisasi agar tujuan organisasi dapat mencapai secara efektif dan efisien. Secara terminologis, definisi manajemen dikemukakan oleh para ahli yang berbeda. Menurut G.R. Terry (2009, h. 1) Manajemen adalah suatu proses yang terdiri atas perencanaan, pengorganisasian, penggerakkan, pelaksanaan dan pengawasan, dengan 
memanfaatkan baik ilmu maupun seni agar dapat menyelesaikan tujuan yang telah ditetapkan sebelumnya (Jaja Jahari, 2013, h. 1). Manajemen adalah suatu proses yang dilakukan agar suatu usaha dapat berjalan dengan baik, memerlukan perencanaan, pemikiran, pengarahan, dan pengaturan serta mempergunakan atau mengikutsertakan semua potensi yang ada, baik personal maupun material secara efektif dan efisien (Badrudin, 2014, h. 20).

Kompetensi adalah kemampuan bersikap, berfikir, dan bertindak secara konsisten sebagai perwujudan dan pengetahuan, sikap dan keterampilan yang dimiliki peserta didik (Rusman, 2012, h. 429). Standar kompetensi adalah ukuran kompetensi minimal yang harus dicapai peserta didik setelah mengikuti suatu proses pembelajaran pada satuan pendidikan tertentu. Kompetensi merupakan perpaduan dari pengetahuan, keterampilan, nilai dan sikap yang direfleksikan dalam kebiasaan berfikir dan bertindak (Muhammad Joko Susilo, 2012, h. 97).

Standar Kompetensi Lulusan (SKL) sebagaimana yang dimaksud oleh Peraturan Pemerintah Nomor 19 tahun 2005, Pasal 1 ayat (4) adalah kualifikasi kemampuan lulusan yang mencakup sikap, pengetahuan dan keterampilan. Standar kompetensi lulusan pada satuan pendidikan menengah umum bertujuan untuk meningkatkan kecerdasan, pengetahuan, kepribadian, akhlak mulia, serta keterampilan untuk hidup mandiri dan mengikuti pendidikan lebih lanjut. Standar Kompetensi Lulusan (SKL) digunakan sebagai pedoman penilaian dalam penentuan kelulusan peserta didik dari satuan pendidikan. Standar Kompetensi Lulusan meliputi kompetensi seluruh mata pelajaran atau kelompok mata pelajaran (E. Mulyasa, 205, h. 91).

Standard of Graduate Competencies (SKL) "The learners in this regard are expected to improve and to balance between the soft skills and hard skills that include aspects of competencies of attitudes (including: personal faith, morality, self-confident, and responsibility in interacting effectively with the social environment, the natural surroundings, as well as the world and its civilization), skills (including: a person having effective and creative thinking in the realm of the abstract and concrete domains), and knowledge (the ability to produce the persons mastering the knowledge, science, technology, arts, and culture that are based on humanity, national, state, and civilization)" (Prihantoro, C. Rudy, 2015, h. 79).

Fungsi utama sekolah/madrasah adalah membelajarkan siswa untuk mencapai standar kompetensi lulusan yang telah ditetapkan baik oleh pemerintah maupun oleh sekolah/madrasah sendiri. Untuk menyusun profil SKL, sekolah/madrasah perlu menggambarkan target pencapaian SKL dan kondisi ril prestasi sekolah/madrasah beberapa tahun terakhir. Beberapa pertanyaan di bawah ini dapat dipakai sebagai panduan dalam menyusun profil terkait dengan standar kompetensi lulusan (Muhaimin, dkk, 2010, h. 255):

1. Apakah presentase kelulusan yang masuk disekolah favorit tingkat kabupaten/kota/provinsi semakin meningkat?

2. Apakah kejuaraan akademik/non akademik tingkat kabupaten/kota/ provinsi/nasional semakin meningkat?

3. Apakah kejuaraan Olimpiade tingkat kabupaten/ kota/ provinsi/ nasional (matematika, fisika dan lain-lain) semakin meningkat?

4. Apakah rata-rata UAN dan UAS semakin meningkat? 
5. Apakah lulusan memiliki penguasaan dan keterampilan TIK?

6. Apakah lulusan telah memenuhi standar kecakapan amaliyah keagamaan?

Standar Kompetensi Lulusan adalah kualifikasi kemampuan lulusan yang mencakup pengetahuan, sikap dan keterampilan. Untuk meningkatkan kompetensi lulusan sekolah/madrasah dapat mengembangkan kurikulum dengan standar yang lebih tinggi pada standar isi dan Standar Kompetensi Lulusan dengan melakukan inovasi, pengembangan, dan perluasan dengan tujuan yang diharapkan dari masing-masing satuan atau jenjang pendidikan.

Berikut ini merupakan Standar Kompetensi Lulusan Mata Pelajaran SAINS/IPA SMP/MTs :

1. Ilmu Pengetahuan Alam SMP/MTs

a. Melakukan pengamatan dengan peralatan yang sesuai, melaksanakan percobaan sesuai prosedur, mencatat hasil pengamatan dan pengukuran dalam tabel dan grafik yang sesuai, membuat kesimpulan dan mengkomunikasikannya secara lisan dan tertulis sesuai dengan bukti yang diperoleh

b. Memahami keanekaragaman hayati, klasifikasi keragamannya berdasarkan ciri, cara-cara pelestariannya, serta saling ketergantungan antar makhluk hidup di dalam ekosistem

c. Memahami sistem organ pada manusia dan kelangsungan makhluk hidup

d. Memahami konsep partikel materi, berbagai bentuk, sifat dan wujud zat, perubahan, dan kegunaannya

e. Memahami konsep gaya, usaha, energi, getaran, gelombang, optik, listrik, magnet dan penerapannya dalam kehidupan sehari-hari

f. Memahami sistem tata surya dan proses yang terjadi di dalamnya.

\section{METODE PENELITIAN}

Penelitian ini mengguanakan penelitian kualitatif. Penelitian di Madrasah Tsanawiyah Negeri 1 Pangandaran, dan objek penelitiannya adalah Peningkatan Kompetensi Lulusan di Madrasah Tsanawiyah Negeri 1 Pangandaran.

Sumber data meliputi: 1) Kepala Madrasah Bapak Drs. H. Yamin, M.Pd, 2) Wakamad Kurikulum Ibu Dra. Hj. Ruhayati, 3) Kasubag TU Ibu Imas Maelani, A.Ma, 4) Guru Mapel Sains Ibu Yuyun Yuniasih, S.Pd. Dan Teknik Pengumpulan Data Meliputi: 1) Wawancara, 2) Observasi, 3) Dokumentasi.

Analisis data dilakukan dengan kategorisasi data penafsiran data. Adapun uji absah dta dilakukan dengan perpanjangan keikutsertaan, ketekunan pengamatan, triangulasi, cek teman sejawat, analisis kasus negatif, kecukupan referensi, uraian rinci dan auditing.

\section{HASIL DAN PEMBAHASAN}

\section{Profil Kompetensi Lulusan Madrasah Tsanawiyah Negeri 1 Pangandaran}

Dalam konteks pendidikan, indikator mutu berpedoman pada konteks hasil pendidikan yang mengacu pada prestasi yang dicapai oleh sekolah pada setiap kurun waktu tertentu (misalnya: setiap catur wulan, semester, setahun, 5 
tahun, dan sebagainya). Prestasi yang dicapai dapat berupa hasil tes kemampuan akademis, seperti: ulangan umum, UN, atau prestasi bidang lain, misalnya prestasi dibidang olah raga dan seni. Bahkan prestasi sekolah berupa kondisi yang tidak dapat dipegang (intangible), seperti suasana disiplin, keakraban, saling menghormati, dan sebagainya (Rusman, 2012, h. 555).

Profil kompetensi lulusan dapat dilihat dari beberapa hasil ujian nasional dalam kurun waktu 3 tahun. Hasil ujian nasional pada kurun waktu 3 tahun sampai sekarang menurut bapak kepala madrasah saat diwawancarai hasil ujian nasional khusunya pada mata pelajaran sains/IPA sesuai dengan target yang diharapkan dan memuaskan. Terbukti dengan adanya peningkatan nilai pada kurun waktu 3 tahun terakhir Berikut merupakan hasil ujian nasional Madrasah Tsanawiyah Negeri 1 Pangandaran khususnya pada mata pelajaran sains/IPA yang mengalami peningkatan:

Tabel 4.2

Kompetensi Lulusan di Madrasah Tsanawiyah Negeri 1 Pangandaran Pada Mata Pelajaran IPA

\begin{tabular}{|c|c|c|c|}
\hline \multirow{2}{*}{ Nilai } & \multicolumn{3}{|c|}{ Tahun Pelajaran } \\
\cline { 2 - 4 } & $2014 / 2015$ & $2015 / 2016$ & $2016 / 2017$ \\
\hline Kategori & $\mathrm{D}$ & $\mathrm{C}$ & $\mathrm{C}$ \\
\hline Rata-rata & 52.99 & 64.77 & 69.09 \\
\hline Rendah & 37.5 & 45.0 & 52.50 \\
\hline Tinggi & 85.0 & 85.0 & 90.00 \\
\hline
\end{tabular}

Jika dicermati dari tabel di atas bahwa nilai hasil ujian nasional pada tahun 2014/2015 khususnya pada mata pelajaran sains/IPA nilai rata-ratanya adalah 52.99 dengan kategori $D$ yaitu kurang baik. Selanjutnya nilai hasil ujian nasional pada tahun $2015 / 2016$ khusunya pada mata pelajaran sains/IPA niali rata-ratanya adalah 64.77 dengan kategori $C$ yaitu cukup baik dan pada tahun ajaran 2016/2017 nilai rata-rata mata pelajaran sains/IPA cukup meningkat menjadi 69.09 dengan kategori C yaitu sudah cukup baik. Maka dapat disimpulkan bahwa manajemen peningkatan kompetensi lulusan madrasah tsanawiyah negeri 1 pangandaran dapat berjalan cukup baik dan sesuai dengan target atau sasaran yang diharapkan.

Standar Kompetensi Lulusan untuk Mata Pelajaran (SKL - MP) IImu Pengetahuan Alam (IPA) di SMP / MTs adalah sbb:

a. Melakukan pengamatan dengan peralatan yang sesuai, melaksanakan percobaan sesuai prosedur, mencatat hasil pengamatan dan pengukuran dalam tabel dan grafik yang sesuai, membuat kesimpulan dan mengkomunikasikannya secara lisan dan tertulis sesuai dengan bukti yang diperoleh.

b. Memahami keanekaragaman hayati, klasifikasi keragamannya berdasarkan ciri, cara-cara pelestariannya, serta saling ketergantungan antar makhluk hidup di dalam ekosistem.

c. Memahami sistem organ pada manusia dan kelangsungan makhluk hidup.

d. Memahami konsep partikel materi, berbagai bentuk, sifat dan wujud zat, perubahan, dan kegunaannya. 
e. Memahami konsep gaya, usaha, energi, getaran, gelombang, optik, listrik, magnet dan penerapannya dalam kehidupan sehari-hari.

f. Memahami sistem tata surya dan proses yang terjadi di dalamnya.

\section{Kebijakan Kompetensi Lulusan di Madrasah Tsanawiyah Negeri 1 Pangandaran pada Mata Pelajaran Sains}

Kebijakan merupakan pedoman untuk bertindak. Pedoman itu biasa saja amat sederhana dan kompleks, bersifat umum atau khusus, luas atau sempit, kabur atau jelas, longgar atau terperinci, bersifat kualitatif atau kuantitatif, publik atau privat. Kebijakan dalam maknanya seperti ini mungkin berupa deklarasi mengenai suatu dasar pedoman bertindak, suatu arah tindakan tertentu, suatu program mengenai aktivitas-aktivitas tertentu, atau suatu rencana.

Berdasarkan hasil penelitian yang telah dibahas sebelumnya bahwa kebijakan kompetensi lulusan Madrasah Tsanawiyah Negeri 1 Pangandaran khususnya pada mata pelajaran sain/IPA kelas IX disesuaikan dengan peraturan pemerintah mengenai standar kompetensi lulusan mata pelajaran sains/IPA. Mengenai kebijakan khusus dari kepala madrasah, peneliti telah melakukan wawancara langsung kepada bapak Drs. H. Yamin, M.Pd selaku kepala madrasah mengatakan bahwa: "Kebijakan kompetensi lulusan madrasah khususnya pada mata pelajaran sains di sesuaikan dengan KKM, yang terlibat dalam membuat kebijakan ialah kepala madrasah, wakamad, dan guru. Mengenai standar kompetensi lulusan madrasah disesuaikan dengan SKL dari peraturan pemerintah. Untuk meralisasikan kebijakan tersebut agar dapat mencapai sasaran ialah dengan cara peningkatan potensi para guru mata pelajaran khususnya guru sains/IPA serta mengadakan pengayaan bagi peserta didik kelas IX dan mengikutsertakan para peserta didik berkompetisi dalam bidang sains pada tingkat madrasah atau yang sering disebut KSM (Kometisi Sains Madrasah).

Selanjutnya Bapak Kepala Madrasah menegaskan bahwa: "Kebijakan tersebut dapat dilihat dari beberapa indikator-indikator tertentu seperti penilaian sikap sehari-hari seperti sopan santun pada setiap warga di madrasah, pengetahuan yang luas serta keterampilan para peserta didik yang dapat di jadikan profil lulusan yang baik. Agar peserta didik dapat mencapai indikatorindikator tersebut khususnya pada mata pelajaran sains maka peserta didik dituntut untuk selalu banyak mengamati lingkungan sekitar, melakukan eksperimen, dan melakukan demonstrasi-demonstrasi agar dapat merubah perilaku peserta didik ke arah yang lebih baik".

Kebijakan kompetensi lulusan madrasah disini sangat sederhana dan terperinci, bersifat umum dan terarah pada suatu rencana serta aktivitasaktivitas khususnya pada pembelajaran sains. Kebijakan tersebut dapat dilihat dari beberapa aspek seperti penilaian sikap, pengetahuan dan keterampilan para peserta didik.

\section{Perencanaan Peningkatan Kompetensi Lulusan Madrasah Tsanawiyah Negeri 1 Pangandaran Pada Mata Pelajaran Sains/IPA}

Hal yang pertama dalam melakukan perencanaan peningkatan kompetensi lulusan khususnya pada mata pelajaran sains/IPA ialah dengan menganalisis isi dari Standar Kompetensi Lulusan (SKL) mata pelajaran 
sains/IPA. Dari hasil penelitian menurut wakamad kurikulum mengatakan bahwa cara untuk memahami dan menganalisis isi SKL tersebut ialah dengan diadakannya In House Training (IHT), worksop, MGMP dan dilakukan pemetaan silabus, Sandar Kompetensi Lulusan, Standar Kompetensi, dan Kompetensi Dasar agar para pendidik khususnya guru mata pelajaran sains dapat mengembangkan isi dari SKL tersebut. Dalam memahami SKL mata pelajaran sains yang harus guru kuasai adalah menguasai isi silabus, menguasai materi, dan melakukan metode-metode pembelajaran yang efektif.

Selanjutnya menurut kepala madrasah yang harus dikuasai dalam memahami isi SKL mata pelajaran sains di madrasah adalah penguasaan materi mata pelajaran khususnya oleh guru sains/IPA. Adapun beberapa cara agar peserta didik dapat mencapai SKL mata pelajaran sains/IPA adalah dengan dilakukannya latihan-latihan tes tulis maupun tes lisan serta demonstrasi dan pengayaan untuk kelas IX. Adapun strategi yang harus dilakukan agar peserta didik mampu mencapai SKL khusunya mata pelajaran sains adalah belajar dengan sungguh-sungguh, pergunakan waktu dengan sebaik mungkin, serta selalu aktif mengikuti kegiatan-kegiatan yang positif yaitu seperti pengayaan di madrasah.

\section{Pelaksanaan Peningkatan Kompetensi Lulusan Madrasah Tsanawiyah Negeri 1 Pangandaran pada Mata Pelajaran Sains/IPA}

Pada tahap pelaksanaan peningkatan kompetensi lulusan madrasah khususnya pada mata pelajaran sains hal yang pertama dilakukan ialah perencanaan pembelajaran mata pelajaran sains yaitu dengan mempersiapkan serta menyusun silabus dan RPP. Komponen silabus mata pelajaran sains di madrasah sudah lengkap meliputi SK, KD, materi pembelajaran, kegiatan pembelajaran, indikator pencapaian kompetensi, penilaian, alokasi waktu dan sumber belajar. Sedangkan untuk RPP mata pelajaran sains sudah tersusun dengan baik dan lengkap meliputi SK, KD, tujuan pembelajaran, materi pembelajaran, metode pembelajaran, langkah-langkah pembelajaran, media pembelajaran, sumber belajar dan penilaian.

\section{Faktor Pendukung dan Faktor Penghambat Peningkatan Kompetensi Lulusan Madrasah Tsanawiyah Negeri 1 Pangandaran}

a. Faktor Pendukung

Dalam mencapai tujuan peningkatan kompetensi lulusan khususnya pada mata pelajaran sains/IPA terdapat beberapa faktor penunjang dan faktor penghambat baik pada proses perencanaan, pelaksanaan peningkatan kompetensi lulusan diantaranya yaitu sebagai berikut:

1) Siswa mempunyai motivasi yang tinggi dalam mengikuti pembelajaran khususnya pembelajaran IPA;

2) Pihak Madrasah mengikutsertakan para peserta didi berkompetisi khususnya pada bidang sains seperti lomba KSM (Kompetisi Sains Madrasah) agar peserta didik dapat mencapai SKL mata pelajaran sains/IPA;

3) Para orang tua peserta didik yang selalu mengapresiasi dan mengontrol hasil belajar anak-anaknya; dengaan menghadiri acara pembagian raport siswa. 
4) Para pendidik yang senantiasa bersemangat dalam menjalankan tugasnya sebagai seorang guru yaitu dengan membuat para peserta didik lebih nyaman untuk mengikuti pembelajaran; dan guru memberikan kesempatan kepada siswa untuk mengemukakan pendapat dan pertanyaan-pertanyaan yang sekiranya siswa masih ada yang belum mengerti.

5) Pihak komite madrasah yang selalu memberikan motivasi serta masukan-masukan yang positif untuk kemajuan lembaga yaitu berupa pemberian reward kepada madrasah yang berprestasi dalam segala bidang;

6) Adanya timbal balik dari lulusan atau alumni yang selalu memberikan motivasi serta nasehat-nasehat kepada adik kelasnya.

b. Faktor Penghambat

1) ruang kelas yang masih kurang baik dari 33 ruang kelas ada 3 ruang kelas yang mengalami kerusakan,

2) ruang laboratorium yang belum maksimal karena masih menggunakan ruang kelas untuk dijadikan ruangan praktikum IPA,

3) Sarana prasarana pendukung pembelajaran berupa kusri, meja, alat peraga dan lainnya yang masih kurang menunjang karena ada yang mengalami kerusakan;

4) Letak Madrasah yang berada di pinggir jalan sehingga proses KBM kurang kondusif karena terganggu oleh lalu lalang kendaraan.

Profil kompetensi lulusan dapat dilihat dari hasil ujian nasional pada kurun waktu 3 tahun yaitu dari tahun ajaran 2014/2015 sampai 2016/2017. Hasil ujian nasional khusunya pada mata pelajaran sains/IPA sudah sesuai dengan target yang diharapkan dan memuaskan. Terbukti dengan adanya peningkatan nilai yang cukup signifikan dari tahun ajaran sebelumnya sampai sekarang seperti tertera pada hasil penelitian yang telah dibahas sebelumnya. Selanjutnya mengenai lulusan atau alumni 99\% dapat melanjutkan ke jenjang sekolah menengah atas sesuai dengan yang mereka inginkan, dan adapun timbal balik dari alumni tang berdampak positif serta dapat memotivasi para peserta didik yang lainnya.

Fungsi utama sekolah/madrasah adalah membelajarkan siswa untuk mencapai standar kompetensi lulusan yang telah ditetapkan baik oleh pemerintah maupun oleh sekolah/madrasah sendiri. Untuk menyusun profil SKL, sekolah/madrasah perlu menggambarkan target pencapaian SKL dan kondisi ril prestasi sekolah/madrasah beberapa tahun terakhir (Muhaimin, dkk, 2010, h. 255).

Dalam kebijakan peningkatan kompetensi lulusan madrasah khususnya pada Mata Pelajaran Sains bahwa kepala madrasah lebih menekankan pada potensi guru yang harus ditingkatkan serta peserta didik diwajibkan mengikuti program pengayaan dan mampu berkompetisi pada bidang sains contohnya mengikutsertakan dalam lomba Kompetisi Sains Madrasah. Kebijakan merupakan pedoman untuk bertindak. Pedoman itu biasa saja amat sederhana dan kompleks, bersifat umum atau khusus, luas atau sempit, kabur atau jelas, longgar atau terperinci, bersifat kualitatif atau kuantitatif, publik atau privat. Kebijakan dalam maknanya seperti ini mungkin berupa deklarasi mengenai 
suatu dasar pedoman bertindak, suatu arah tindakan tertentu, suatu program mengenai aktivitas-aktivitas tertentu, atau suatu rencana.

Berdasarkan hasil penelitian Ana Hariatul Qurjiah dalam jurnal Peningkatan keterampilan wirausaha melalui keterampilan tata busana dan Relevansinya dengan Standar Kompetensi Lulusan (SKL) bahwa proses dalam pelaksanaan peningkatan keterampilan tata busana meliputi perencanaan, pelaksanaan dan evaluasi.

Dalam merencanakan peningkatan kompetensi lulusan di Madrasah Tsanawiyah Negeri 1 Pangandaran khususnya mata pelajaran sains setiap guru memperhatikan beberapa aspek yaitu menyusun analisis SKL , analisis materi pelajaran, menyusun program tahunan, menyusun program semester, dan menyusun program satuan pelajaran serta para guru mata pelajaran melakukan musyawarah guru mata pelajaran serta melakukan pemetaan silabus, SKL, SK dan KD pada awal tahun sebelum masuk tahun ajaran baru dimulai.

Pada pelaksanaan peningkatan kompetensi lulusan madrasah pada mata pelajaran sains/IPA dimulai dengan perencanaan pembelajaran khususnya mata pelajaran sains yaitu dengan mempersiapkan serta menyusun silabus dan RPP. Komponen silabus mata pelajaran sains di madrasah sudah lengkap meliputi SK, KD, materi pembelajaran, kegiatan pembelajaran, indikator pencapaian kompetensi, penilaian, alokasi waktu dan sumber belajar. Sedangkan untuk RPP mata pelajaran sains sudah tersusun dengan baik dan lengkap meliputi SK, KD, tujuan pembelajaran, materi pembelajaran, metode pembelajaran, langkah-langkah pembelajaran, media pembelajaran, sumber belajar dan penilaian.

Berdasarkan hasil penelitian Ana Hariatul Qurjiah dalam jurnal Peningkatan keterampilan wirausaha melalui keterampilan tata busana dan Relevansinya dengan Standar Kompetensi Lulusan (SKL) terdapat beberapa faktor pendukung dalam pelaksanaan keterampilan wirausaha. Faktor pendukung dalam keterampilan ini lebih pada sarana prasarana yang ada serta motivasi yang ada dalam diri peserta didik karena motivasi mampu menciptakan situasi dalam diri untuk berbuat dan berperilaku sesuai dengan apa yang dikehendaki.

Faktor pendukung dalam peningkatan kompetensi lulusan Madrasah Tsanawiyah Negeri 1 Pangandaran khususnya pada mata prlajaran sains diantaranya ada beberapa faktor yaitu siswa mempunyai motivasi yang tinggi dalam mengikuti pembelajaran khususnya pembelajaran IPA; Mengikutsertakan para peserta didi berkompetisi pada bidang sains seperti lomba KSM (Kompetisi Sains Madrasah) agar peserta didik dapat mencapai SKL mata pelajaran sains/IPA; Para orang tua peserta didik yang selalu mengapresiasi dan mengontrol hasil belajar anak-anaknya; Para pendidik yang senantiasa bersemangat dalam menjalankan tugasnya sebagai seorang guru yaitu dengan membuat para peserta didik lebih nyaman untuk mengikuti pembelajaran; Pihak komite madrasah yang selalu memberikan motivasi serta masukan-masukan yang positif untuk kemajuan lembaga yaitu berupa pemberian reward kepada madrasah yang berprestasi dalam segala bidang; Adanya timbal balik dari lulusan atau alumni yang selalu memberikan motivasi serta nasehat-nasehat kepada adik kelasnya. 
Faktor penghambat dalam peningkatan kompetensi lulusan Madrasah Tsanawiyah Negeri 1 Pangandaran khususnya pada mata prlajaran sains diantaranya ada beberapa faktor yaitu ruang kelas yang masih kurang baik yaitu dari 33 ruang kelas ada 3 ruang kelas yang mengalami kerusakan, ruang laboratorium yang belum maksimal karena masih menggunakan ruang kelas untuk dijadikan ruangan praktikum IPA, sarana prasarana pendukung pembelajaran berupa kusri, meja, alat peraga dan lainnya yang masih kurang menunjang karena ada yang mengalami kerusakan; letak Madrasah yang berada di pinggir jalan sehingga proses KBM kurang kondusif karena terganggu oleh lalu lalang kendaraan.

\section{SIMPULAN}

Berdasarkan penelitan yang dilaksanakan di Madrasah Tsanawiyah Negeri 1 Pangandaran mengenai Manajemen Peningkatan Kompetensi Lulusan Madrasah Tsanawiyah Negeri 1 Pangandaran khususnya pada mata pelajaran sains/IPA sebagai berikut: profil kompetensi lulusan dapat dilihat dari hasil ujian nasional pada kurun waktu 3 tahun yaitu dari tahun ajaran 2014/2015 sampai 2016/2017. Hasil ujian nasional khusunya pada mata pelajaran sains/IPA sudah sesuai dengan target yang diharapkan dan memuaskan. Terbukti dengan adanya peningkatan nilai yang cukup signifikan dari tahun ajaran sebelumnya sampai sekarang seperti tertera pada hasil penelitian yang telah dibahas sebelumnya. Standar Kompetensi Lulusan untuk mata pelajaran (SKL - MP) Ilmu Pengetahuan Alam (IPA) di SMP / MTs berdasarkan Lampiran Permendiknas 23 Tahun 2006, Tanggal 23 Mei 2006 yang terlampir dalam hasil penelitian. Kebijakan kompetensi lulusan madrasah khususnya pada mata pelajaran sains di sesuaikan dengan KKM, mengenai standar kompetensi lulusan madrasah disesuaikan dengan SKL dari peraturan pemerintah. Untuk meralisasikan kebijakan tersebut agar dapat mencapai sasaran ialah dengan cara peningkatan potensi para guru mata pelajaran khususnya guru sains/IPA serta mengadakan pengayaan bagi peserta didik kelas IX dan mengikutsertakan para peserta didik berkompetisi dalam bidang sains pada tingkat madrasah atau yang sering disebut KSM (Kometisi Sains Madrasah).Dalam perencanaan peningkatan kompetensi lulusan madrasah khususnya mata pelajaran sains setiap guru memperhatikan beberapa aspek yaitu menyusun dan menganalisis SKL , serta para guru mata pelajaran melakukan musyawarah guru mata pelajaran serta melakukan pemetaan silabus, SKL, SK dan KD pada awal tahun sebelum masuk tahun ajaran baru dimulai. Pelaksanaan peningkatan kompetensi lulusan madrasah pada mata pelajaran sains/IPA dimulai dengan perencanaan pembelajaran khususnya mata pelajaran sains yaitu dengan mempersiapkan serta menyusun silabus dan RPP. Komponen silabus mata pelajaran sains di madrasah sudah lengkap meliputi SK, KD, materi pembelajaran, kegiatan pembelajaran, indikator pencapaian kompetensi, penilaian, alokasi waktu dan sumber belajar. Sedangkan untuk RPP mata pelajaran sains sudah tersusun dengan baik dan lengkap meliputi SK, KD, tujuan pembelajaran, materi pembelajaran, metode pembelajaran, langkah-langkah pembelajaran, media pembelajaran, sumber belajar dan penilaian. Faktor penunjang dan penghambat dalam peningkatan Kompetensi Lulusan Madrasah TsanawiyahNegeri 1 Pangandaran. Faktor 
pendukung terlihat dari sarana prasarana pembelajaran yang ada sudah cukup memadai;media pembelajaran disesuaikan dengan kebutuhan pembelajaran khususnya mata pelajaran sains/IPA; Sumber belajar yang cukup lengkap adanya buku paket serta alat-alat peraga; dand iadakannya workshop serta percobaan atau ekperimen agar peserta didik dapat mencapai SKL mata pelajaran sains/IPA. Ada beberapa faktor penghambat diantaranya infrastruktur yang masih kurang baik seperti atu ruang kelas yang rusak berat, alat-alat peraga yang belum maksimal, media pembelajaran yang masih kurang mendukung.

\section{REFERENSI}

Badrudin. (2014). Manajemen Peserta Didik. Jakarta: PT Indeks Jahari, J. (2013). Manajemen Madrasah". Bandung: Alfabeta.

Muhaimin. (2012). Pengembangan Kurikulum Pendidikan Agama Islam di Sekolah, Madrasah, dan Perguruan Tinggi. Jakarta: PT RajaGrafindo Persada

Muhaimin. et.al., (2010). Manajemen Pendidikan: Aplikasi dalam Penyusunan Rencana Pengembangan Sekolah/Madrasah. Jakarta: Kencana Prenada Media Group

Susilo, M. J. (2012). Kurikulum Tingkat satuan Pendidikan: Manajemen

Pelaksanaan dan Kesiapan Sekolah Menyongsongnya. Yogyakarta:

Pustaka Pelajar.

Mulyasa. 2005. Menjadi Guru Profesional, Menciptakan Pembelajaran Kreatif dan Menyenangkan. Bandung: PT. Remaja Roosdakarya.

Peraturan Menteri Pendidikan dan Kebudayaan Nomor 54 Tahun 2013 tentang Standar Kompetensi Lulusan Pendidikan Dasar dan Menengah

Peraturan Menteri Pendidikan dan Kebudayaan Nomor 20 Tahun 2016 Tentang Standar Kompetensi Lulusan Pendidikan Dasar Dan Menengah

Prihantoro, C. R. (2015). The perspective of curriculum in Indonesia on environmental education. International Journal of Research Studies in Education Volume 4 Number 1, 77-83 halaman

Qurjiah, A. H. (Skripsi), (2015), Peningkatan Keterampilan Wirausaha melalui keterampilan Tata Busana dan Relevansinya dengan Standar Kompetensi Lulusan. STAIN Ponorogo

Rusman (2011). Model-model Pembelajaran (Mengembangkan Profesionalisme Guru). Jakarta: Rajawali Pers.

Zamroni, (2013). Manajemen Pendidikan: Suatu Usaha Meningkatkan Mutu Sekolah. Bandung: Alfabeta 
Siti Maesaroh 